\title{
Universidad y género
}

University and gender

Francisco Luis Pacheco Caballero

Catedrático de Universidad

Historia del Derecho.

Universidad de Barcelona.

E-mail: flpacheco@)ub.edu

No soy especialista en estudios de género. Cumplo aquí con un a todas luces inmerecido encargo para presentar este número de la Revista dedicado a Género y Universidad y lo hago, insisto, no como especialista sino como alguien que, desde su disciplina -la Historia del Derecho y de las Instituciones- se ha tenido que ocupar de las raíces históricas de la desigualdad en sentido amplio y, por lo tanto, también, de la larga desigualdad entre hombres y mujeres. No puedo aportar nada al debate que no hayan dicho ya, por ejemplo, Inmaculada López-Francés y Victoria Vázquez Verdera sobre la perspectiva de género y el papel de la Universidad del siglo XXI, que no hayan dicho ya Ana Acosta Sarmiento e Inma Pastor Gosálbez sobre institucionalización de las políticas de igualdad de género en la Universidad española o que no hayan dicho ya Juna Carlos Gavara de Cara y José Carlos Remotti Carbonell sobre el gobierno de las Universidades y la perspectiva de género, trabajos y nombres que el especialista reconocerá inmediatamente, por ceñirme a momentos cercanos y al ámbito hispánico . Desde luego, no puedo apartar nada nuevo al debate que no puede leerse en las contribuciones que siguen en la sección monográfica de este número de la Revista. Y tampoco, en fin, puedo aportar nada nuevo al ya nada nuevo empeño de las múltiples normativas y, especialmente, todas aquellas que tienen que ver con el mundo de la ciencia, enderezado a que las correspondientes regulaciones incluyan una perspectiva de género. Como jurista historiador sólo puedo, pues, constatar la existencia histórica de una desigualdad y el señalamiento, aunque no sea ahora el momento, de unas raíces históricas y reflexionar breve y retóricamente en torno a si, a pesar de lo ocurrido después de 1789, han mejorado las cosas. 
Como ya he tenido de manifestar en otras ocasiones, y ahora no hago sino repetir cosas ya dichas, no formulado, antes de la Revolución Francesa, el principio de igualdad ante la ley o, como se dice ahora, el principio de isonomía cívica, el jurista historiador sabe que la desigualdad constitutiva característica de las sociedades anteriores a ese momento, tenía amparo, en lo que hace a la desigualdad entre hombres y mujeres, en el mismo discurso legal y en el discurso religioso. Sin tener que acudir ahora a la tan manida misoginia de San Pablo o las imágenes que se transmiten de Eva y Magdalena, la así caracterizada como imbecillitas sexus o fragilitas sexus justificaba planteamientos androcéntricos en virtud de los cuales se podía afirmar abiertamente, que de mejor condición es el varon que la mujer en muchas cosas e en muchas

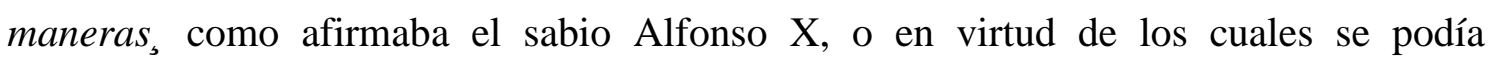
rechazar, en el ámbito del proceso, el testimonio de las mujeres salvo que versase sobre aquello que, por su condición, las mujeres conocen de primera mano: Numquam mulieres ad testimonium admittuntur nisi in his que in balneis feminarum fiunt, como se advertía en Lérida en el siglo XIII, aunque en Miravet se amplió a lo que las mujeres habían visto u oído, también, en el horno. Aunque algunos no se lo hayan terminado de creer, desde 1789, los hombres (incluidas en este caso las mujeres porque los redactores de la Déclaration desconocían la noción de lenguaje inclusivo) nacen y permanecen libres e iguales en derecho, sin que las distinciones sociales puedan tener más fundamento que las derivadas de la utilidad pública, principio que, recogido en la forma que sea, con mayor o menor intensidad, inspira al constitucionalismo contemporáneo, al punto de advertirse, en aquel momento, que toda organización política en la que no estuviese asegurada la garantía de los derechos que asisten a esos hombres libres e iguales no tiene, propiamente, Constitución. Aunque algunos y, en este caso, también algunas tampoco se lo hayan terminado de creer, la Constitución Española proclama la igualdad de los españoles ante ley sin que sea posible la discriminación por razón, entre otras circunstancias, de sexo, lo que, hasta donde se me alcanza, significa el reconocimiento de la igualdad de hombres y mujeres ante la ley. La contraposición de la realidad histórica de una larga desigualdad a la realidad de la proclamación de la igualdad ha provocado que el discurso postmoderno y el gusto por la microhistoria y el microrrelato, después de la cacareada crisis de los grandes relatos, se haya centrado en el estudio de la marginalidad y de los factores de exclusión y por el estudio de las raíces históricas de la desigualdad. Los estudios feministas y la toma en consideración de la perspectiva de género, como una categoría de análisis apta para el estudio de las 
diferencias en función y por razón de sexo, han convertido a las mujeres en objeto y materia del discurso.

Como puede desprenderse de las contribuciones de los especialistas que he citado al principio, La Universidad, como centro de reflexión, no es ajena a este debate. No ya, solo, por la imperiosa necesidad de adecuar las correspondientes normativas universitarias al principio de igualdad. Además de normativas y regulaciones que todos tienen en mente, bastaría un vistazo, por ejemplo, al Codi Ètic d'Integritat i Bones Pràctiques de la Universidad de Barcelona, para identificar los esfuerzos en tal sentido. No ya, solo, porque de loables iniciativas en el seno de la comunidad universitaria se deriven reconocimientos más o menos anecdóticos de la igualdad entre hombres y mujeres o reconocimientos más o menos anecdóticos de la identidad femenina y de sus logros. Me refiero a la necesidad de una reflexión crítica sobre los retos actuales de la Universidad como centro en que se forman ciudadanos en la igualdad entre hombres y mujeres y como centro en el que, según los especialistas y los indicadores de género, todavía no se han desterrado de las prácticas de su funcionamiento, al margen de proclamas legales, aquellas concepciones androcéntricas que desembocan en situaciones de injusticia por razón de sexo, ni se han desterrado aquellas prácticas que, sobre una evidente igualdad de capacidades, derivan, sin embargo, en una desigualdad en relación al acceso al conocimiento. Que una Revista como Educación y Derecho dedique unos estudios a reflexionar y profundizar sobre estos problemas no puede ser sino motivo de satisfacción. 